University of Nebraska - Lincoln

DigitalCommons@University of Nebraska - Lincoln

\title{
Microbial Reduction of Fe(III) and Sorption/Precipitation of Fe(II) on Shewanella putrefaciens Strain CN32
}

\author{
Chongxuan Liu \\ Pacific Northwest National Laboratory, chongxuan.liu@pnl.gov \\ John M. Zachara \\ Pacific Northwest National Laboratory, john.zachara@pnl.gov \\ Yuri Gorby \\ Pacific Northwest National Laboratory \\ Jim Szecsody \\ Pacific Northwest National Laboratory \\ Christopher Brown \\ Pacific Northwest National Laboratory
}

Follow this and additional works at: https://digitalcommons.unl.edu/usdoepub

Part of the Bioresource and Agricultural Engineering Commons

Liu, Chongxuan; Zachara, John M.; Gorby, Yuri; Szecsody, Jim; and Brown, Christopher, "Microbial Reduction of Fe(III) and Sorption/Precipitation of Fe(II) on Shewanella putrefaciens Strain CN32" (2001). US Department of Energy Publications. 219.

https://digitalcommons.unl.edu/usdoepub/219

This Article is brought to you for free and open access by the U.S. Department of Energy at DigitalCommons@University of Nebraska - Lincoln. It has been accepted for inclusion in US Department of Energy Publications by an authorized administrator of DigitalCommons@University of Nebraska - Lincoln. 
Microbial Reduction of Fe(III) and Sorption/Precipitation of Fe(II) on Shew anella putrefaciens Strain CN32

CHONGXUAN LIU, * JOHN M. ZACHARA, YURI A. GORBY, JIM E. SZECSODY, AND CHRISTOPHER F. BROWN

Pacific Northwest National Laboratory, P.O. Box 999, MSIN K8-98, Richland, Washington 99352

The influence of $\mathrm{Fe}(\mathrm{II})$ on the dissimilatory bacterial reduction of an $\mathrm{Fe}(\mathrm{III})$ aqueous complex (Fe(III)- citrate $_{\text {aq }}$ ) was investigated using Shewanella putrefaciens strain CN32. The sorption of Fe(II) on CN 32 followed a Langmuir isotherm. Least-squares fitting gave a maximum sorption capacity of $Q_{\max }=4.19 \times 10^{-3} \mathrm{~mol} / 10^{12}$ cells $(1.19 \mathrm{mmol} /$ $\mathrm{m}^{2}$ of cell surface area) and an affinity coefficient of log $K=3.29$. The growth yield of $\mathrm{CN} 32$ with respect to $\mathrm{Fe}(\mathrm{III})_{\mathrm{aq}}$ reduction showed a linear trend with an average value of $5.24( \pm 0.12) \times 10^{9} \mathrm{cell} / \mathrm{s} / \mathrm{mmol}$ of $\mathrm{Fe}(\mathrm{III})$. The reduction of $\mathrm{Fe}(\mathrm{III})_{\text {aq }}$ by $\mathrm{CN} 32$ was described by Monod kinetics $w$ ith respect to the electron acceptor concentration, $\mathrm{Fe}(I I I)_{\text {aq, }}$ with a half-saturation constant $\left(K_{\mathrm{s}}\right)$ of $29( \pm 3)$ $\mathrm{mM}$ and maximum growth rate $\left(\mu_{\max }\right)$ of $0.32( \pm 0.02) \mathrm{h}^{-1}$. However, the pretreatment of CN 32 with $\mathrm{Fe}(\mathrm{II})_{\text {aq }}$ significantly inhibited the reduction of $\mathrm{Fe}(\mathrm{III})_{\mathrm{aq}}$, resulting in a lag phase of about $3-30 \mathrm{~h}$ depending on initial cell concentrations. Lower initial cell concentration led to longer lag phase duration, and higher cell concentration led to a shorter one. Transmission electron microscopy and energy dispersive spectroscopy revealed that many cells carried surface precipitates of Fe mineral phases (valence unspecified) during the lag phase. These precipitates disappeared after the cells recovered from the lag phase. The cell inhibition and recovery mechanisms from Fe(II)-induced mineral precipitation were not identified by this study, but several alternatives were discussed. A modified Monod model incorporating a lag phase, Fe(II) adsorption, and aqueous complexation reactions was able to describe the experimental results of microbial $\mathrm{Fe}(\mathrm{III})_{\text {aq }}$ reduction and cell growth when cells were pretreated with $\mathrm{Fe}(\mathrm{II})_{\text {aq }}$.

\section{Introduction}

Dissimilatory iron-reducing bacteria (DIRB) are important to the biogeochemical cycling of iron in anoxic sediments and groundwaters (1-4). DIRB can also degrade both natural $(4-7)$ and synthetic (8-10) organic materials and indirectly influence the fate and transport of polyvalent metals, trace elements, and radionuclides (3, 11-13).

There are many factors that influence the rate of iron (III) oxide reduction by DIRB. These factors include the following: direct contact between organisms and iron oxides

* Correspondingauthor phone: (509)376-0129; fax: (509)376-3650; e-mail: chongxuan.liu@pnl.gov.
(14-16); crystallinity, particlesizeand surfacearea, and phase identity of the iron(III) oxides $(1,14,17-21)$; sorption of ferrous iron (22-26); ferrous iron biomineralization $(23,24)$; presence of electron shuttles such as humic substance $(23$, $24,27,28)$; and organic ligands that enhance iron oxide dissolution or Fe(II) solubilization (18, 29).

This study and a recent publication (25) have found that $\mathrm{Fe}(\mathrm{II})$ sorbsto DIRB cells. However, a clear assessment of the effects of Fe(II) biosorption on the Fe(III) reduction rate has not been reported. Biosorption of Fe(III) on bacterial surfaces was reported to promote Fe(III) mineral precipitation (30), but whether the precipitated Fe(II) affects bacterial growth and Fe(III) reduction has not been established. In iron(III) oxide suspensions, an evaluation of theimportance of Fe(II) biosorption is complicated by the complexity of the DIRBiron(III) oxide biophysical association, competitive interactions between the cell and oxide surfaces, and potential ternary interaction. U rrutia et al. (25) found that the reduction rate of goethite by Shewanella alga (BrY) was slowed by $\mathrm{Fe}(\mathrm{II})$ addition, suggesting that Fe(II) sorption to DIRB inhibited bacterial reduction. However, the interpretation of those results was complicated by the fact that Fe(II) was more strongly sorbed to goethite and that mass transfer of $\mathrm{Fe}(\mathrm{II})$ from the cells to goethite may have occurred. A recent study (22) found that thereduction rate of goethite was slowed by Fe(II) sorption. These limited observations emphasize the need to understand the impact of the biosorption of $\mathrm{Fe}(\mathrm{II})$ on the reduction of Fe(III) by DIRB becausetheprocess invariably occurs in the environment and, under certain circumstances, may be rate limiting.

The Monod rate expression (31) is often used to describe microbial growth and single substrate degradation kinetics. It has also been extended to include cases where electron acceptors are limiting the growth rate (dual Monod kinetics) $(32,33)$. The dual Monod kinetic expression has been widely applied in reactive transport models to describe the rates of microbial growth with respect to substrate and electron acceptor concentrations (33-44). However, the applicability of the Monod model with respect to electron acceptor concentration has not been independently tested against experimental data for bacterial Fe(III) reduction. In fact, saturation-type kinetics have only been observed for iron(III) oxide reduction at low solid concentrations $(14,18)$. In many cases, only a limited fraction of the iron(III) oxide provided as an electron acceptor can be reduced by DIRB due to various factors described above and others that are unknown. Under such circumstances, saturation-type kinetics have not been observed (e.g., refs 21-24).

This study had two objectives. The first was to independently establish the influence of Fe(II) biosorption on the dissimilatory microbiologic reduction rate of Fe(III). To avoid the complications of competitive sorption reactions in a multiphasesystem (e.g., microbes and iron oxides) and other poorly understood interfacial phenomena, Fe(III)aq (as the citrate complex) was used as the electron acceptor. Citrate maintains the solubility of $\mathrm{Fe}(\mathrm{III})$ in aqueous phase and influences the distribution of $\mathrm{Fe}(\mathrm{II})$ between the aqueous phase and DIRB cells through the formation of aqueous complexes. The second objective was to test the applicability of the Monod kinetic model with respect to electron acceptor concentration and to develop a kinetic model describing the coupled effect of Fe(II) biosorption on DIRB reduction rate. The experimental conditions were simple and designed to (i) independently estimate sorption and reduction kinetic parameters and (ii) experimentally measure their coupling. 


\section{Experimental Procedures}

Bacteria. Shewanella putrefaciens strain CN32 (Subsurface Microbial Culture Collection) was provided courtesy of Dr. David Boone (Portland State University). Strain CN32 was isolated from an anaerobic subsurface core sample ( $250 \mathrm{~m}$ beneath thesurface) obtained from the Morrison Formation in northwestern New Mexico. The details of culturing procedures and CN32 cell harvest were described elsewhere $(23,24)$. CN32 cells were routinely cultured aerobically in tryptic soy broth (TSB), $30 \mathrm{~g} / \mathrm{L}$ (Difco Laboratories, Detroit, $\mathrm{MI}$ ), and harvested by centrifugation from TSB cultures. The cells were then washed with 1,4-piperazinediethanesulfonic acid (PIPES) buffer (pH 7) purged with $\mathrm{O}_{2}$-depleted $\mathrm{N}_{2}\left[\mathrm{~N}_{2}\right.$ gas was passed through a tube containing heated copper filings to reduce $\mathrm{O}_{2}$ concentration in the $\mathrm{N}_{2}$ gas to below detection limit (50 ppb)] to remove residual TSB. Harvested CN32 cells were resuspended in PIPES buffer to the required concentrations for sorption experiments and in media buffered with PIPES for iron reduction experiments.

Sorption Experiments. The sorption experiments determined the equilibrium distribution of $\mathrm{Fe}(\mathrm{II})$ between the aqueous phase and CN32. The experimental sorption isotherm was used to analyze the effects of sorption on the bacterial reduction rate expression. In the sorption experiments, CN32 cells were mixed with a range of Fe(II) concentrations $(0.01-6.00 \mathrm{mM})$ in Falcon tubes with PIPES buffer ( $\mathrm{pH}$ 7.0, $30 \mathrm{mM}$ of PIPES) in an anaerobic chamber (Coy Laboratory Products, Inc., Ann Arbor, MI). Thesorption measurements were performed without lactate or other electron donors $(3,27)$. All samples were equilibrated for 24 h with continuous mixing (100 rpm). Kinetic experiments indicated that the biosorption reaction reached equilibrium in less than $30 \mathrm{~min}$. After 24 -h equilibration, the bacterial suspensions were filtered $(0.2 \mu \mathrm{m})$, and the filtrate was acidified $(1 \mathrm{~N} \mathrm{HCl})$. Fe(II) in the acidified filtrates was measured by the ferrozine assay (20). The sorbed concentration was calculated by the difference between the Fe(II)tot and final aqueous Fe(II) concentration.

Four sets of sorption experiments were performed with three different cell concentrations. The first two sets of sorption experiments had cell concentrations of $2 \times 10^{8}$ and $7 \times 10^{7}$ cells $/ \mathrm{mL}$, respectively, and $\mathrm{Fe}(\mathrm{II})_{\text {tot }}$ concentrations of $0.50,1.00,2.00,4.00$, and $6.00 \mathrm{mM}$. The other two sets of experiments had cell concentrations of $5 \times 10^{8}$ and $7 \times 10^{7}$ cells/mL, respectively, with two more points at the lower end of the Fe(II) concentration range ( 0.01 and $0.025 \mathrm{mM})$.

Ferric-Citrate Reduction Experiments. The culture medium that was used for the ferric-citrate reduction experiments was described elsewhere $(23,24)$. The composition of the medium was (mM) as follows: $\mathrm{NH}_{4} \mathrm{Cl}(25.0), \mathrm{Na}_{2}-$ $\mathrm{HPO}_{4}(0.44), \mathrm{KCl}(1.20), \mathrm{CaCl}_{2} \cdot 2 \mathrm{H}_{2} \mathrm{O}(0.61), \mathrm{MgSO}_{4} \cdot 7 \mathrm{H}_{2} \mathrm{O}$ (1.1), $\mathrm{NaCl}$ (1.5), and $\mathrm{MnSO}_{4} \cdot \mathrm{H}_{2} \mathrm{O}$ (0.27). The medium was buffered to $\mathrm{pH} \approx 7.0$ with PIPES (30 $\mathrm{mM}$ ) buffer, purged with $\mathrm{O}_{2}$-depleted $\mathrm{N}_{2}$ gas, stoppered with butyl rubber closures, and crimp sealed. L-Lactate (Sigma Chemicals) was used as a carbon source and electron donor.

The growth experiments were performed with initial CN32 concentrations of $10^{6}-10^{7}$ cells/ $\mathrm{mL}, 20-25 \mathrm{mM}$ Fe(III)citrate as an electron acceptor, and $30 \mathrm{mM}$ lactate as an electron donor. The ratio between $\mathrm{Fe}(\mathrm{III})$ reduction and lactate degradation is approximately $4: 1$; lactate is oxidized to acetateand $\mathrm{CO}_{2}$ by $\mathrm{CN} 32$ under Fe(III)-reducing conditions $(23,24)$. Excess lactate was used to prevent electron donor limitation. Citrate, a complexing agent, stabilizes Fe(III) in the aqueous phase. Citrate also forms Fe(II) complexes with higher stability constants [Fe(II)-citrate, log $\mathrm{K}=5.68$; $\mathrm{Fe}(\mathrm{II})-\mathrm{H}$-citrate, $\log \mathrm{K}=9.91$ (45)] than the cell surface (log $\mathrm{K}=3.29$ ). Aqueous samples were acidified $(1 \mathrm{~N} \mathrm{HCl})$ and analyzed by the ferrozine assay. The concentration of CN32

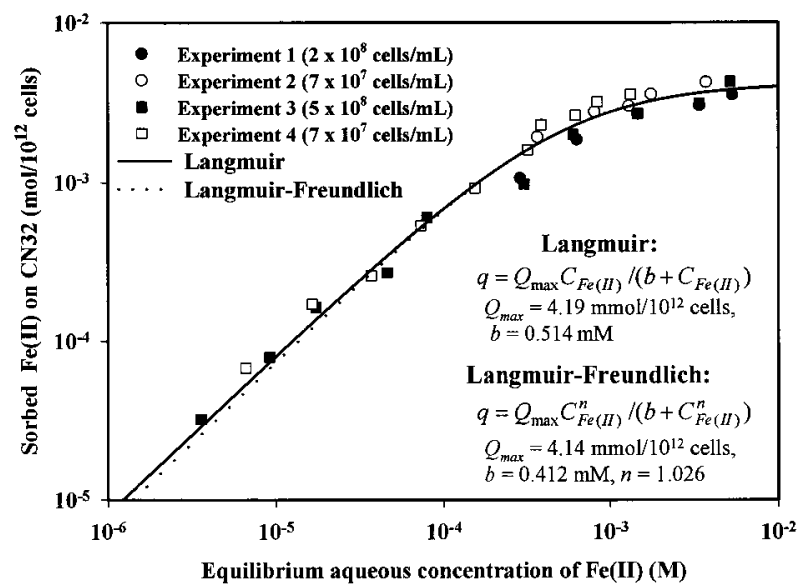

FIGURE 1. Isotherm for Fe(II) sorption on S. putrefaciens, strain CN32.

cells was immediately counted after sampling using the Acridine Orange Direct Count (AODC) method.

The growth medium [e.g., Fe(III)-citrate $($ aq) $]$ in selected experiments was spiked with $1-2 \mathrm{mM} \mathrm{Fe}(\mathrm{II})\left(\mathrm{FeCl}_{2}\right)$ to examine the influence of biosorbed $\mathrm{Fe}(\mathrm{II})$ on the $\mathrm{Fe}(\mathrm{III})$ reduction rate. The $\mathrm{Fe}(\mathrm{II})$ concentration was chosen to saturate the cell surfaces based on the measured sorption isotherm (this study) after consideration for Fe(II) aqueous complexation. The Fe(II) spike provided excess iron to the medium over citrate. All reduction experiments were performed with PIPES buffer (pH 7) and at $25^{\circ} \mathrm{C}$.

Transmission Electron Microscopy. Samples for transmission electron microscopy (TEM) were prepared in an anaerobic glovebox to avoid oxidation of Fe(II). Cell suspensions were centrifuged at $5000 \mathrm{~g}$ for 5 min using a tabletop centrifuge. Harvested cells were washed 3 times in an anaerobic solution of $30 \mathrm{mM}$ PIPES buffer at pH 7. Droplets of washed cell suspensions were placed upon Formvarcarbon support films on copper grids. Excess liquid was wicked away using a small piece of filter paper, and samples were dried in the anaerobic glovebox. Dehydrated samples were sealed in air-tight canning jars for transport to the electron microscope. Samples were exposed to aerobic conditions for less than $1 \mathrm{~min}$ while being transferred to the high vacuum sample chamber of a JEOL 2010 TEM. The unstained preparations were examined with an acceleration voltage of $200 \mathrm{kV}$. The elemental composition of cellassociated precipitates was obtained using energy dispersive spectroscopy (EDS) (Oxford Instruments).

\section{Results and Discussion}

Sorption. The sorbed Fe(II) concentrations in all four sets of experiments were normalized to a cell number of $10^{12}$ cells (Figure 1). The sorption isotherm was approximately linear for aqueous $\mathrm{Fe}(\mathrm{II})$ concentrations below $10^{-4} \mathrm{M}$; it then gradually level ed off at higher concentration, consistent with the Langmuir sorption behavior. Theexperimental data were first fitted to a mixed Langmuir-Freundlich sorption isotherm (dotted line, $\mathrm{R}^{2}=0.935,3$ parameters: $\mathrm{Q}_{\max }, \mathrm{b}$, and n) using nonlinear least-squares regression. The fitted results indicated that the sorption reaction could be well approximated by the Langmuir isotherm $(n=1.026)$. The data then were refitted to Langmuir isotherm (solid line, $\mathrm{R}^{2}=$ 0.934, 2 parameters: $Q_{\max }$ and b). The least-squares fitting gave a maximum sorption capacity of $\mathrm{Q}_{\max }=4.19 \times 10^{-3}$ $\mathrm{mol} / 10^{12}$ cells and an affinity constant between CN32 and $\mathrm{Fe}(\mathrm{II})$ of $\mathrm{K}(=1 / \mathrm{b})=10^{3.29} \mathrm{M}^{-1}$. The values of $\mathrm{Q}_{\max }$ and $\mathrm{K}$ were close to those fitted from the mixed Langmuir-Freundlich sorption isotherm: $Q_{\max }=4.14 \times 10^{-3} \mathrm{~mol} / 10^{12}$ cells and $\mathrm{K}$ $=10^{3.38} \mathrm{M}^{-1}$. The Freundlich sorption isotherm $(\mathrm{q}=$ 
TABLE 1. Growth Yield with Respect to Fe(III) Reductiona

\begin{tabular}{lcccc}
\multicolumn{1}{c}{ bacteria } & electron donor & type of Fe(III) & yield $\left(\times \mathbf{1} \mathbf{0}^{\mathbf{9}}\right.$ cells $/ \mathbf{m m o l}$ of Fe(III)) & source \\
GS-15 & acetate & amorphous iron(III) oxide & 4.3 & $(6)$ \\
GS-15 & phenol & amorphous iron(III) oxide & 5.5 & $(9)$ \\
GS-15 & p-cresol & amorphous iron(III) oxide & 5.7 & $(9)$ \\
S. alga $(\mathrm{BrY})$ & lactate & goethite & 2.2 & $(21)$ \\
S. alga (BrY) & $\mathrm{H}_{2}$ & goethite & 2.0 & $(21)$ \\
S. putrefaciens (CN32) & lactate & aqueous Fe(III) & 5.2 & this work \\
a The yield values were calculated from the cell number increase during the growth phase divided by the amount of Fe(II) produced over that \\
time period.
\end{tabular}

$\left.\mathrm{K}_{\mathrm{F}} \mathrm{C}_{\mathrm{Fe}(I I)}^{1 / \mathrm{n}}\right)$, which was previously used to describe $\mathrm{Fe}(\mathrm{II})$ sorption to $\mathrm{S}$. alga ( $\mathrm{BrY}$ ) (25), gave an inferior fit to the observed data. A possible explanation for this difference is that the concentration rangeused in the previous experiments may not have been high enough to reach the saturation. Nonetheless, the maximum sorption capacity $\left(Q_{\max }\right)$ estimated by ref 25 was $0.1 \mathrm{mmol} F e(\mathrm{II}) / \mathrm{g}$ of dry BrY cells, which is about $4.5 \times 10^{-3} \mathrm{~mol} / 10^{12}$ cells using a ratio of $45 \mathrm{~g}$ dry weight/ $10^{12}$ cells provided by the authors (25). This value was close to our estimate for $\mathrm{CN} 32\left(\mathrm{Q}_{\max }=4.19 \times 10^{-3} \mathrm{~mol} /\right.$ $10^{12}$ cells).

The estimated Langmuir sorption capacity $\left(Q_{\max }\right)$ yields a saturation value of $2.5 \times 10^{9} \mathrm{Fe}(\mathrm{II})$ ions/ cell. If we assume that CN 32 has cylindrical shapewith a size of $0.5 \mu$ m diameter $\times 2 \mu$ m length, then $\mathrm{Q}_{\max }$ translates into an adsorption density of $1.19 \mathrm{mmol} / \mathrm{m}^{2}$. This number greatly exceeds the cation sorption capacity of iron(III) oxides (e.g., $4-27 \mu \mathrm{mol} / \mathrm{m}^{2}$ on goethite) (46). The surface-induced precipitation of Fe(II) solids could lead to a high, apparent biosorption capacity. However, in anaerobic PIPES buffer, $\mathrm{Fe}(\mathrm{OH})_{2}$ is the only known potential precipitate, and thermodynamic calculation excludes homogeneous precipitation assuming that the free energy data are correct. The computed solubility of $\mathrm{Fe}(\mathrm{OH})_{2}$ is about $79 \mathrm{mM}$ at pH 7 (using log $\mathrm{K}_{\mathrm{sp}}=-15.1$ for $\mathrm{Fe}(\mathrm{OH})_{2}$ from ref 45), which is an order of magnitude higher than our highest Fe(II) aq.

Bacterial cell walls display a strong affinity for a wide variety of aqueous metal cations (e.g., refs 47-56). The functional groups on cell walls, carboxyl (R-COO-) and phosphryl(R-POO-) appear to bethe dominant binding sites $(53,55,57,58)$. On Bacillussubtilis, the divalent metals $\mathrm{Cu}^{2+}$, $\mathrm{Pb}^{2+}$, and $\mathrm{Cd}^{2+}$ were complexed by carboxylic groups at neutral $\mathrm{pH}$, with affinity constant (log K) around 3-4.5 and capacity of $0.12 \mathrm{mmol} / \mathrm{g}(55)$. Although thereareno previous reports of $\mathrm{Fe}(\mathrm{II})$ biosorption affinity with bacteria (53), our results suggest that Fe(II) was complexed by surface carboxyl groups on the membrane surface because the estimated affinity constant for $\mathrm{Fe}(\mathrm{II})(\log \mathrm{K}=3.3)$ and sorption capacity $\left(4.19 \times 10^{-3} \mathrm{~mol} / 10^{12}\right.$ cells $\left.\approx 0.10 \mathrm{mmol} / \mathrm{g}\right)$ were close to thosereported for other divalent metals on carboxylic groups, and the single-site Langmuir model fitted the sorption data well.

DIRB Yield with theFe(III) Reduction. Theapparent yield of $\mathrm{CN} 32$ cell growth with $\mathrm{Fe}(\mathrm{III})$ reduction followed an approximate linear trend (Figure 2). The yield was defined as the amount of cell growth resulting from $\mathrm{Fe}(\mathrm{III})$ reduction. The average yield value was $5.24 \times 10^{9} \mathrm{cell} / \mathrm{s} / \mathrm{mmol}$ of Fe(III). This value compares favorably to ones calculated from the literature where different forms of Fe(III), electron donors, and DIRB were used (Table 1). The observed linear trend for cell yield allowed direct application of the Monod kinetic model to describe cell growth and its effects on the Fe(III) reduction.

DIRB Reduction of Ferric-Citrate. AM onod kinetic rate expression was developed with respect to electron acceptor concentration $\mathrm{Fe}(\mathrm{III})$ and cell growth that was applied to the experimental data (Figure 3). The electron donor (lactate)

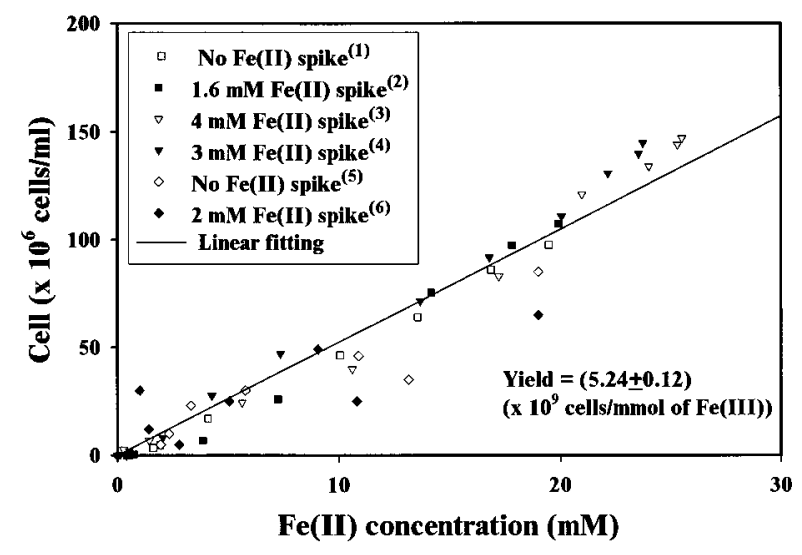

FIGURE 2. CN32 cell growth yield with the reduction of Fe(III)citrate as an electron acceptor under various initial conditions: (1) $20 \mathrm{mM}$ ferric-citrate and $2.2 \times 10^{6}$ cells $/ \mathrm{mL}$; (2) $20 \mathrm{mM}$ ferriccitrate, $2.2 \times 10^{6}$ cells $/ \mathrm{mL}$, and $1.6 \mathrm{mM} \mathrm{FeCl}$; (3) $24 \mathrm{mM}$ ferriccitrate and $1.0 \times 10^{6}$ cells $/ \mathrm{mL}\left(4.0 \mathrm{mM} \mathrm{FeCl}{ }_{2}\right.$ spiked when cells reached $9.5 \times 10^{7}$ cells $/ \mathrm{mL}$ ); (4) $24 \mathrm{mM}$ ferric-citrate, $1.0 \times 10^{6}$ cells $/ \mathrm{mL}$, and $1.0 \mathrm{mM} \mathrm{FeCl}$ (another $2.0 \mathrm{mM} \mathrm{FeCl}$ spiked when cells reached $4.8 \times 10^{7}$ cells $/ \mathrm{mL}$ ); (5) $22 \mathrm{mM}$ ferric - citrate and 7.4 $\times 10^{7}$ cells $/ \mathrm{mL}$; (6) $22 \mathrm{mM}$ ferric -citrate, $7.4 \times 10^{7}$ cells $/ \mathrm{mL}$, and $2 \mathrm{mM} \mathrm{FeCl}$.

was in excess (30 mM) in all experiments. The model was mathematically described as follows:

Fe(III) reduction

$$
\frac{\mathrm{dT}_{\mathrm{Fe}(I I I)}}{\mathrm{dt}}=-\frac{\left(\mu_{\max } / \mathrm{Y}\right) \mathrm{C}_{\mathrm{X}} \mathrm{T}_{\mathrm{Fe}(\mathrm{III})}}{\mathrm{K}_{\mathrm{s}}+\mathrm{T}_{\mathrm{Fe}(\mathrm{III})}}
$$

cell growth

$$
\frac{\mathrm{dC}_{\mathrm{X}}}{\mathrm{dt}}=\frac{\mu_{\mathrm{max}} \mathrm{C}_{\mathrm{X}} \mathrm{T}_{\mathrm{Fe}(I I I)}}{\mathrm{K}_{\mathrm{s}}+\mathrm{T}_{\mathrm{Fe}(I I I)}}
$$

Fe(II) production

$$
\frac{\mathrm{dT}_{\mathrm{Fe}(I I)}}{\mathrm{dt}}=-\frac{\mathrm{dT}_{\mathrm{Fe}(\mathrm{III})}}{\mathrm{dt}}
$$

In eqs $1-3, \mathrm{~T}_{\mathrm{Fe} \text { (III) }}$ is the total $\mathrm{Fe}(\mathrm{III})$ concentration, $\mathrm{T}_{\mathrm{Fe}(\mathrm{II})}$ is the total $\mathrm{Fe}(\mathrm{II})$ concentration, $\mathrm{C}_{\mathrm{x}}$ is the cell concentration, $\mathrm{t}$ is the time, $\mu_{\max }$ is the maximum growth rate, $\mathrm{Y}$ is the cell yield with respect to $\mathrm{Fe}(\mathrm{III})$ reduction, and $\mathrm{K}_{\mathrm{s}}$ is the halfsaturation constant with respect to total Fe(III).

The parameter $Y$ was determined from the yield curve (Figure 2). The parameters $\mathrm{K}_{\mathrm{s}}$ and $\mu_{\max }$ were estimated by minimizing the least-squares errors between calculated $T_{\text {Fe(II) }}$ and measured $\mathrm{Fe}(\mathrm{II})_{\text {(tot) }}$ data using a modified LevenbergMarquardt nonlinear fitting method (59). The best fit to the $\mathrm{Fe}(\mathrm{II})_{\text {(tot) }}$ data (Figure 3a,b) gave $\mathrm{K}_{\mathrm{s}}=29( \pm 3) \mathrm{mM}$ and $\mu_{\max }$ $=0.32( \pm 0.02) \mathrm{h}^{-1}$ (numbers in parenthesesare onestandard 
TABLE 2. Aqueous Speciation Models for the Fe(III)-Citrate System

model

reaction

$\log K^{a}$

citation

ASM-I

ASM-II

$$
\mathrm{Fe}^{3+}+\text { citrate }^{3-}=\mathrm{Fe}(\mathrm{III}) \text { citrate }^{0}
$$

$$
\begin{aligned}
& \mathrm{Fe}^{3+}+\text { citrate }^{3-}+\mathrm{H}^{+}=\mathrm{Fe}(\mathrm{III}) \mathrm{Hcitrate}^{+} \\
& \mathrm{Fe}^{3+}+2 \text { citrate }^{3-}=\mathrm{Fe}(\mathrm{III}) \text { citrate }_{2}{ }^{3-} \\
& \mathrm{Fe}^{3+}+\text { 2citrate }^{3-}+\mathrm{H}^{+}=\mathrm{Fe}(\mathrm{III}) \mathrm{Hcitrate}_{2}^{-} \\
& \mathrm{Fe}^{3+}+2 \text { citrate }^{3-}+2 \mathrm{H}^{+}=\mathrm{Fe}(\mathrm{III}) \mathrm{H}_{2} \text { Citrate }_{2}{ }^{+} \\
& \mathrm{Fe}^{3+}+\text { citrate }^{3-}+\mathrm{H}_{2} \mathrm{O}-\mathrm{H}^{+}=\mathrm{Fe}(\mathrm{III}) \mathrm{OHcitrate}- \\
& \mathrm{Fe}^{3+}+\text { citrate }^{3-}+\mathrm{H}_{2} \mathrm{O}-\mathrm{H}^{+}=\mathrm{Fe}(\mathrm{III}) \mathrm{OHcitrate}{ }^{4-} \\
& \mathrm{Fe}^{3+}+2 \text { citrate }^{3-}+2 \mathrm{H}_{2} \mathrm{O}-2 \mathrm{H}^{+}=\mathrm{Fe}(\mathrm{III})(\mathrm{OH})_{2} \text { citrate }_{2}{ }^{5-} \\
& \mathrm{Fe}^{3+}+2 \mathrm{citrate}^{3-}+3 \mathrm{H}_{2} \mathrm{O}-3 \mathrm{H}^{+}=\mathrm{Fe}(\mathrm{III})(\mathrm{OH})_{3} \text { citrate }_{2}{ }^{6-} \\
& \mathrm{Fe}^{3+}+\text { citrate }^{3-}+2 \mathrm{PO}_{4}^{3-}+4 \mathrm{H}^{+}+\mathrm{H}_{2} \mathrm{O}=\mathrm{Fe}(\mathrm{OH})\left(\mathrm{H}_{2} \mathrm{PO}_{4}\right)_{2}(\mathrm{H} \text {-citrate })^{2-} \\
& \mathrm{Fe}^{3+}+\text { citrate }^{3-}+\mathrm{PO}_{4}{ }^{3-}+3 \mathrm{H}^{+}+\mathrm{H}_{2} \mathrm{O}=\mathrm{Fe}(\mathrm{OH})\left(\mathrm{H}_{2} \mathrm{PO}_{4}\right)\left(\mathrm{H}_{2} \text { - citrate }\right)^{0} \\
& \mathrm{Fe}^{3+}+2 \text { citrate }^{3-}+2 \mathrm{PO}_{4}{ }^{3-}+5 \mathrm{H}^{+}+\mathrm{H}_{2} \mathrm{O}=\mathrm{Fe}(\mathrm{OH})\left(\mathrm{H}_{2} \mathrm{PO}_{4}\right)_{2}(\mathrm{H} \text {-citrate })_{2}{ }^{4-}
\end{aligned}
$$$$
14.33
$$$$
\begin{aligned}
& 19.12 \\
& 23.46
\end{aligned}
$$$$
26.38
$$
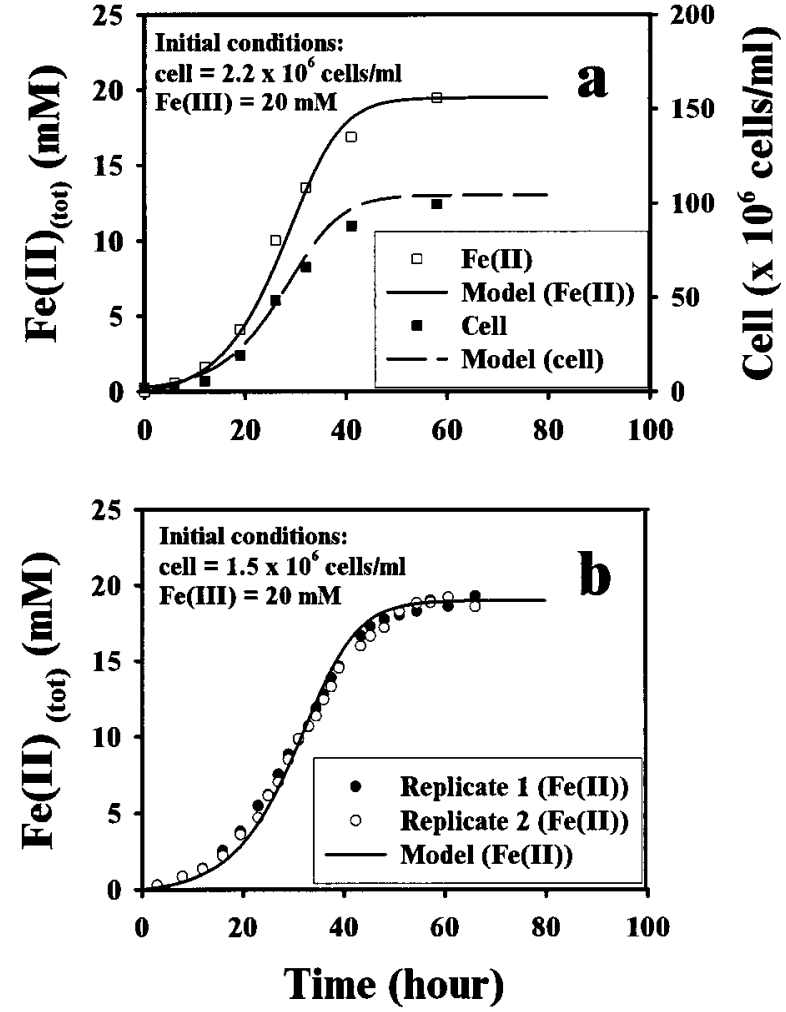

FIGURE 3. Experimental and modeling results for $\mathrm{CN} 32$ grow th and $\mathrm{Fe}$ (III) reduction (showing $\mathrm{Fe}$ (II) production). (a) Fe(II) production and cell grow th; (b) Fe(II) production with a different initial cell concentration. The $\mathrm{Fe}$ (II) concentrations in panels a and $\mathrm{b}$ were fitted using a Monod model with two parameters (half-saturation coefficient, $K_{\mathrm{s}}=29 \pm 3 \mathrm{mM}$; maximum grow th rate, $\mu_{\max }=0.32$ $\left.\pm 0.02 \mathrm{~h}^{-1}\right)$. The yield value, $Y\left(=5.24 \pm 0.12\left(\times 10^{9} \mathrm{cells} / \mathrm{mmol}\right.\right.$ of $\mathrm{Fe}(\mathrm{III}))$, used in the model $w$ as determined from Figure 2 . The cell concentration in panel a was simulated by the model.

deviation). The measured cell concentration in Figure 3a was simulated by the model. The M onod kinetic relationship

\begin{tabular}{|c|c|c|}
\hline reaction & $\log K$ & source \\
\hline $\begin{array}{l}\mathrm{Fe}^{2+}+\text { citrate }^{3-}=\mathrm{Fe}(\mathrm{II}) \mathrm{citrate}^{-} \\
\mathrm{Fe}^{2+}+\text { citrate }^{3-}+\mathrm{H}^{+}=\mathrm{Fe}(\mathrm{II}) \mathrm{Hcitrate}^{0} \\
\mathrm{Fe}^{2+}+\text { acetate }^{-}=\mathrm{Fe}(\mathrm{II}) \text { acetate }^{+} \\
\mathrm{Fe}^{2+}+\text { lactate }^{-}=\mathrm{Fe}(\mathrm{II}) \text { lactate } \\
\mathrm{Fe}^{2+}+\mathrm{H}_{2} \mathrm{O}-\mathrm{H}^{+}=\mathrm{Fe}(\mathrm{II}) \mathrm{OH}^{+} \\
\mathrm{Fe}^{2+}+2 \mathrm{H}_{2} \mathrm{O}-2 \mathrm{H}^{+}=\mathrm{Fe}(\mathrm{II})(\mathrm{OH})_{2}{ }^{0} \\
\mathrm{Fe}^{2+}+3 \mathrm{H}_{2} \mathrm{O}-3 \mathrm{H}^{+}=\mathrm{Fe}(\mathrm{II})(\mathrm{OH})_{3}- \\
\mathrm{Fe}^{2+}+\mathrm{SO}_{4}^{2-}=\mathrm{Fe}\left(\mathrm{III} \mathrm{SO}_{4}{ }^{0}\right. \\
\mathrm{Fe}^{2+}+\mathrm{H}_{2} \mathrm{PO}_{4}=\mathrm{Fe}(\mathrm{II}) \mathrm{H}_{2} \mathrm{POO}_{4}^{+} \\
\mathrm{Fe}^{2+}+\mathrm{HPO}_{4}^{2-}=\mathrm{Fe}(\mathrm{II}) \mathrm{HPO}_{4}{ }^{0} \\
\mathrm{Fe}^{2+}+\mathrm{CO}_{3}^{2-}=\mathrm{Fe}(\mathrm{II}) \mathrm{CO}_{3}{ }^{0} \\
\mathrm{Fe}^{2+}+\mathrm{HCO}_{3}{ }^{2-}=\mathrm{Fe}(\mathrm{II}) \mathrm{HCO}_{3}{ }^{+}\end{array}$ & $\begin{array}{r}13.43 \\
9.91 \\
1.40 \\
1.82 \\
-9.50 \\
-20.57 \\
-13.19 \\
2.25 \\
22.25 \\
15.95 \\
4.47 \\
12.32\end{array}$ & $\begin{array}{l}(45) \\
(45) \\
(45) \\
(14) \\
(45) \\
(45) \\
(45) \\
(45) \\
(45) \\
(45) \\
(45) \\
(45)\end{array}$ \\
\hline
\end{tabular}
well described the time-variant bioevolution of Fe(II) (tot) and cell growth with time (Figure 3). However, the magnitude of the estimated half-saturation constant, $K_{s}$, was high as compared with the surface site concentration of CN32 as determined from the Fe(II) sorption isotherm $(4.19 \mu \mathrm{M}$ per $10^{6} \mathrm{cells} / \mathrm{mL}$ ). The high $\mathrm{K}_{\mathrm{s}}$ value indicated that a minor, complexed Fe(III) species was being used as the substrate for iron reduction by CN32. Assuming the existence of that specific species with its concentration expressed as $\mathrm{C}_{\mathrm{Fe}(I I I)}$,
TABLE 3. Thermodynamic Information for Fe(II) Used in Speciation Calculations

the true $\mathrm{K}_{\mathrm{s}}^{\mathrm{Fe}(I I I)}$ value in Monod model would be $\mathrm{K}_{\mathrm{s}}^{\mathrm{Fe}(I I I)} \approx$

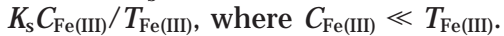

We were unable at this point to speculate on the identity of the substrate Fe(III) species because the speciation of the Fe(III)-citrate system is not well resolved. Two different thermodynamic models have been proposed for complexed species between Fe(III) and citrate in the Fe(III)-citrate system based on potentiometry (ASM-I and ASM-II; Table 2), but neither has been spectroscopically validated. These two thermodynamic models were separately input into the thermodynamic database of the MINTEQA2 code and used for speciation calculations. The calculations indicated that free $\mathrm{Fe}(\mathrm{III})$ was much too low in concentration $\left(<10^{-10} \mathrm{M}\right)$ to function as a viable electron acceptor. The two models predict different speciation at the $\mathrm{pH}$ of the bioreduction studies; Fe(III )citrate was the dominant species with ASM-I, while $\mathrm{FeOH}$ citrate ${ }^{-}$and $\mathrm{Fe}(\mathrm{OH})_{3}\left(\right.$ citrate $_{2}{ }_{2}^{6-}$ were dominant with ASM-II. Thetwo models also predict different speciation changes as Fe(III) is reduced [e.g., with changes to the $\mathrm{Fe}(\mathrm{III})$ :citrate ratio] because of the different stoichiometries of citrate in the complexes. It is not known which of these models, if any, is correct.

Our kinetic model (containing eqs 1-3) well described the experimental data (Figure 3) without incorporation of $\mathrm{Fe}(\mathrm{II})$ speciation and sorption effects. When the speciation of Fe(II) was computed using MINTEQA2 through the course of the bioreduction experiments using thereactions in Tables 2 and 3, it was found that the speciation of Fe(II) and the predicted concentration of sorbed Fe(II) were very different depending on which of thetwo ferric-citratethermodynamic models were used (ASM-I or ASM-II). With ASM-I, the dominant $\mathrm{Fe}(\mathrm{II})$ species through the course of experiment was computed to be Fe(II)citrate $(>97 \%)$. The sorbed concentration of Fe(II) was computed to be small $\left(4 \mu \mathrm{M} / 10^{7}\right.$ 

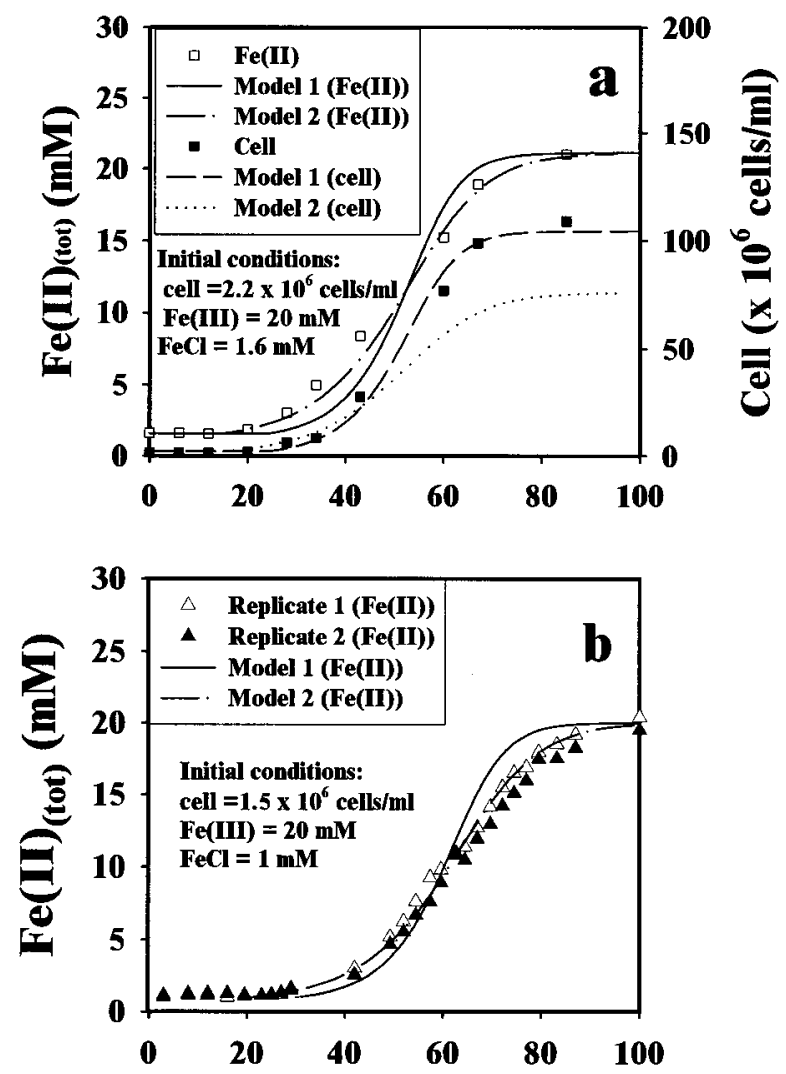

FIGURE 4. Experimental and modeling results for $\mathrm{CN} 32$ grow th and $\mathrm{Fe}$ (III) reduction (show ing $\mathrm{Fe}$ (II) production). Experimental conditions in panels $a$ and $b$ are the same as in Figure 3, panels $a$ and $b$, respectively, excepthere the cell suspensions w ere initially spiked with $1 \mathrm{mM} \mathrm{FeCl}$. Model 1 used the same parameters as in Figure 3 modified by a lag phase. The fitted lag times in Figure 4, panels $a$ and $b$ were 25 and $30 \mathrm{~h}$, respectively. Model 2 used the same parameters as in Figure 3 and a term to account for $\mathrm{Fe}$ (II) competitive inhibition. The fitted lag times in panels $a$ and $b$ were 16 and 20 $h$, respectively, and affinity reduction parameter $K_{\mathrm{i}}=0.35$ for both cases.

cells $/ \mathrm{mL},<10 \%$ of the sorption sites) because citrate outcompeted the cell surface for Fe(II). Significantly more free $\mathrm{Fe}(\mathrm{II})(>1 \mathrm{mM})$ was computed to exist over the intermediate stages of $\mathrm{Fe}(\mathrm{III})$ reduction [2-19 $\mathrm{mM} \mathrm{Fe}(\mathrm{II})_{\mathrm{T}}$ produced] with ASM-II because of the inclusion of dual citrate complexes $\left[\mathrm{Fe}(\mathrm{III})(\mathrm{OH})_{3}(\text { citrate })_{2}{ }^{6-}\right]$ in the speciation scheme that was more competitive for citrate than was Fe(II). Over this intermediatestage of Fe(III) reduction, the cell surfaces were computed to besaturated with sorbed Fe(II). Thus, if ASM-II combined with theDavies convention for activity coefficients were a reasonable speciation model for the ferric-citrate system (note, the application of the Davies model to highly charged complexes is problematic), it may be concluded that $\mathrm{Fe}(\mathrm{II})$ biosorption has minimal effects on both the rate of cell growth and Fe(III) reduction. This conclusion seems contrary to previous literature reports.

Effects of Fe(II) Spikeon Fe(III) Reduction Rate. Adding a concentration of $\mathrm{Fe}(\mathrm{II})$ that was sufficient to saturate the surface of CN32 at the initiation of the bioreduction experiment had a significant impact on Fe(III) bioreduction and cell growth rates. Both of these showed a lag phase of about $20 \mathrm{~h}$ (Figure 4) as compared with the non-Fe(II)-spiked experiment (Figure 3), indicating an inhibiting effect of $\mathrm{Fe}(\mathrm{II})$. However, after about $20 \mathrm{~h}$ of lag phase, the cells began to grow and reduce the Fe(III) aq in manner comparable to those for the unspiked experiments. The reduction rate in the exponential growth phase was only slightly lower in Fe(II)-spiked experiment (Figure4) than without Fe(II) spike
(Figure 3), while the cell growth rates were almost identical (Figures 3a and 4a).

An induction period for the anaerobic bacterial degradation of organic compounds isnot uncommon (60-63). During this period, the bacteria adapts its macromolecular composition (consisting of cell envelope, protein, RNA, and DNA) to prepare for degradation (64-67). The lag phase in Fe(II)-spiked experiments indicated that cells with membranebound $\mathrm{Fe}(\mathrm{II})$ need a similar induction period to reduce $\mathrm{Fe}(\mathrm{III})$. However, the molecular cause and mechanism may be different. Additional studies of this lag phase and cell recovery are presented in the next section.

Because of the similarity of the Fe(III) reduction and cell growth curves (excluding lag phase) in experiments with (Figure 4) and without (Figure 3) Fe(II) spike, wefirst modeled the Fe(II)-spiked case by explicitly adding a lag phase to the Monod model used in Figure 3 (eqs 5-7). The lag function was defined as $(39,68)$

$$
L(t)=\left[\begin{array}{ll}
=0 & t \leq t_{l a g} \\
=1 & t>t_{l a g}
\end{array}\right.
$$

With this lag function, a modified Monod model can be expressed as (model 1)

$$
\begin{gathered}
\frac{\mathrm{dC}_{\mathrm{Fe}(I I I)}}{\mathrm{dt}}=-\mathrm{L}(\mathrm{t}) \frac{\left(\mu_{\mathrm{max}} / \mathrm{Y}\right) \mathrm{C}_{\mathrm{X}} \mathrm{T}_{\mathrm{Fe}(I I I)}}{\mathrm{K}_{\mathrm{s}}+\mathrm{T}_{\mathrm{Fe}(I I I)}} \\
\frac{\mathrm{dC}_{\mathrm{X}}}{\mathrm{dt}}=\mathrm{L}(\mathrm{t}) \frac{\mu_{\mathrm{max}} \mathrm{C}_{\mathrm{X}} \mathrm{T}_{\mathrm{Fe}(I I I)}}{\mathrm{K}_{\mathrm{s}}+\mathrm{T}_{\mathrm{Fe}(I I I)}} \\
\frac{\mathrm{dT}_{\mathrm{Fe}(I I)}}{\mathrm{dt}}=-\frac{\mathrm{dT}_{\mathrm{Fe}(I I I)}}{\mathrm{dt}}
\end{gathered}
$$

Using the Monod parameters determined from Figure 3, we fitted this modified Monod model to the Fe(II) production curves (model 1 in Figure 4 ) by adjusting tlag. The fitted $t_{\text {lag }}$ was $25 \mathrm{~h}$ in Figure $4 \mathrm{a}$ and $30 \mathrm{~h}$ in Figure 4b. The higher initial cell concentration had shorter lag period. Cell growth (Figure 4a) and theFe(II) production (Figure 4a,b) were well described by this model, although the observed $\mathrm{Fe}(\mathrm{III})$ reduction rates were slightly lower than those calculated in the exponential growth phase.

The reduction rate decrease in the exponential growth phase in Fe(II)-spiked cases may relateto an inhibiting effect of $\mathrm{Fe}(\mathrm{II})$. The biosorption of $\mathrm{Fe}(\mathrm{II})$ may affect $\mathrm{Fe}(\mathrm{III})$ cell binding in ways that interfere with the electron transfer process. Both divalent and trivalent metals can be competitively sorbed on cell membranes (53). The initial saturation of the cell surface with Fe(II) may consume surface binding sites for $\mathrm{Fe}(\mathrm{III})$, reducing the chance for direct enzymatic contact with Fe(III).

To evaluate the possible effect of $\mathrm{Fe}(\mathrm{II})$ competitive inhibition on the calculated reduction rates, we added an $\mathrm{Fe}$ (II) competitive inhibition term to the modified Monod model with a lag function (eqs 5-7). The potential effect of sorbed Fe(II) may be derived from enzyme kinetics with competitive inhibition:

$$
\begin{aligned}
& \text { cell }+\mathrm{Fe}(\mathrm{III}) \Leftrightarrow \text { cell }-\mathrm{Fe}(\mathrm{III}) \rightarrow \\
& \qquad \mathrm{Fe}(\mathrm{II})+\text { cell } \Leftrightarrow \mathrm{Fe}(\mathrm{II})-\text { cell }
\end{aligned}
$$

A mathematical expression for reactions described by eq 8 coupled with a lag function can be expressed as

$$
\frac{\mathrm{dT}_{\mathrm{Fe}(I I I)}}{\mathrm{dt}}=-\mathrm{L}(\mathrm{t}) \frac{\left(\mu_{\max } / \mathrm{Y}\right) \mathrm{C}_{\mathrm{X}} \mathrm{T}_{\mathrm{Fe}(I I I)}}{\mathrm{K}_{\mathrm{s}}+\mathrm{T}_{\mathrm{Fe}(I I I)}+\mathrm{K}_{\mathrm{i}} \mathrm{K}_{\mathrm{Fe}(I I)-\text { cell }} \mathrm{K}_{\mathrm{s}}^{\mathrm{Fe}(I I I)} \mathrm{C}_{\mathrm{Fe}(I I)}}
$$




$$
\begin{gathered}
\frac{d C_{X}}{d t}=-L(t) \frac{\mu_{\max } C_{X} T_{F e(I I I)}}{K_{s}+T_{F e(I I I)}+K_{i} K_{F e(I I)-c e l l} K_{s}^{F e(I I I)} C_{F e(I I)}} \\
\frac{d T_{F e(I I)}}{d t}=-\frac{d T_{F e(I I I)}}{d t}
\end{gathered}
$$$$
\mathrm{T}_{\mathrm{Fe}(I I)}=\mathrm{C}_{\mathrm{Fe}(I I)}+\mathrm{C}_{\mathrm{Fe}(I)-\text { citrate }}+\mathrm{C}_{\mathrm{Fe}(I)-\text { Hcitrate }}+
$$$$
\mathrm{C}_{\mathrm{Fe}(\mathrm{II}) \text {-lactate }}+\mathrm{C}_{\mathrm{Fe}(\mathrm{II}) \text {-acetate }}+\mathrm{C}_{\mathrm{Fe}(\mathrm{II}) \text {-cell }}
$$

where $\mathrm{C}_{\mathrm{Fe}(\mathrm{II})}$ is the aqueous $\mathrm{Fe}(\mathrm{II})$ concentration; $\mathrm{C}_{\mathrm{Fe}(\mathrm{II}) \text {-citrate, }}$

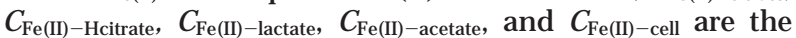
concentrations of complexed $\mathrm{Fe}(\mathrm{II})$ species; $\mathrm{K}_{\mathrm{Fe}(\mathrm{II}) \text {-cell }}$ is the binding constant between $\mathrm{Fe}(\mathrm{II})$ and the cell estimated from the sorption isotherm; and $\mathrm{K}_{i}$ is inhibition coefficient accounting for partial reduction of $\mathrm{Fe}(\mathrm{III})$ affinity with the cell by Fe(II) sorption. Other parameters are as described before.

Equations 9-12 and the five equilibrium equations for Fe(II) - citrate, Fe(II)-Hcitrate, Fe(II)-lactate, Fe(II) - acetate, and $\mathrm{Fe}(\mathrm{II})$-cell were added to complete the model (model 2 in Figure 4). The ambiguities between ASM-I and ASM-II were bypassed by not explicitly considering Fe(III) speciation; Fe(III)-citrate was simply considered a 1:1 complex. Thus, the citrate concentration available for Fe(II) complexation equaled the $\mathrm{Fe}(\mathrm{II})$ concentration, and acetate and lactate were computed from the linear stoichiometry of the bioreduction reaction. The lag time ( $t_{\text {lag }}$ ) and $K_{i}$ in eqs 9-12 were estimated from the Fe(II) production profiles with the $\mathrm{Fe}(\mathrm{II})$ spike. The fitted $\mathrm{K}_{\mathrm{i}}$ was 0.35 , and $\mathrm{t}_{\text {lag }}=16 \mathrm{~h}$ in Figure $4 \mathrm{a}$ and $20 \mathrm{~h}$ in Figure 4b. Model 2 better described Fe(II) production than did model 1 , but model 1 provided a better description of cell growth. Generally, the differences between the two modified Monod models were small.

Fe(II)-Induced Lag Phase and Fe Mineral Precipitation on Cell Surfaces. Theaddition of Fe(II) during theexponential growth phase did not terminate the Fe(III) reduction and cell growth regardless of whether the initial condition was one without or with an Fe(II) spike (Figure 5a). However, Fe(III) reduction and cell growth decreased in theexperiment that received two repeated Fe(II) additions when the cell suspension reached $4.8 \times 10^{7}$ cells $/ \mathrm{mL}$ (solid circles and triangles in Figure 5a). There was no effect of Fe(II) addition on growing cells at $10^{8}$ cells/ $\mathrm{mL}$ (open circles and triangles in Figure 5a) where cells started growth from conditions without Fe(II). These results implied that thetiming of Fe(II) addition or cell number was an important factor controlling $\mathrm{Fe}(\mathrm{II})$-induced inhibition. The significance of cell number, specifically, was confirmed by using higher initial cell concentrations $\left(7.4 \times 10^{7}\right.$ cells/ mL, Figure $\left.5 \mathrm{~b}\right)$. Thelag phase duration decreased to $3 \mathrm{~h}$ with higher cell concentration.

Femineral precipitation was observed on the cell surfaces during thelag phase. TEM images of cells from ferric-citrate suspension without Fe(II) spike showed no Fe enrichment or precipitation on cell surfaces (Figure 6a). However, when the cell suspension was initially spiked with Fe(II), heavy enrichment of Fe or Fe mineral precipitation on some cell surfaces was observed (Figure 6b). Other cells in the Fe(II)spiked suspensions did not contain surface precipitates and appeared identical to Figure $6 a$. The sample for Figure $6 b$ was collected about $2 \mathrm{~h}$ after Fe(II) spiking (solid circles and triangles in Figure 5a). After $15 \mathrm{~h}$, but still in lag phase, Fe was still precipitated on some cell surfaces (Figure $6 c$ ) in this same experiment. However, the image showed the presence of small $(100 \mathrm{~nm})$ membrane vesicles that arise from outer membrane of this Gram-negative bacterium (Figure $6 c$ ). These vesicles may be formed as a potential means of cell membranes in shedding the Fe precipitation. Samples collected from the exponential growth phase of this same experiment showed that all cells were free of surface
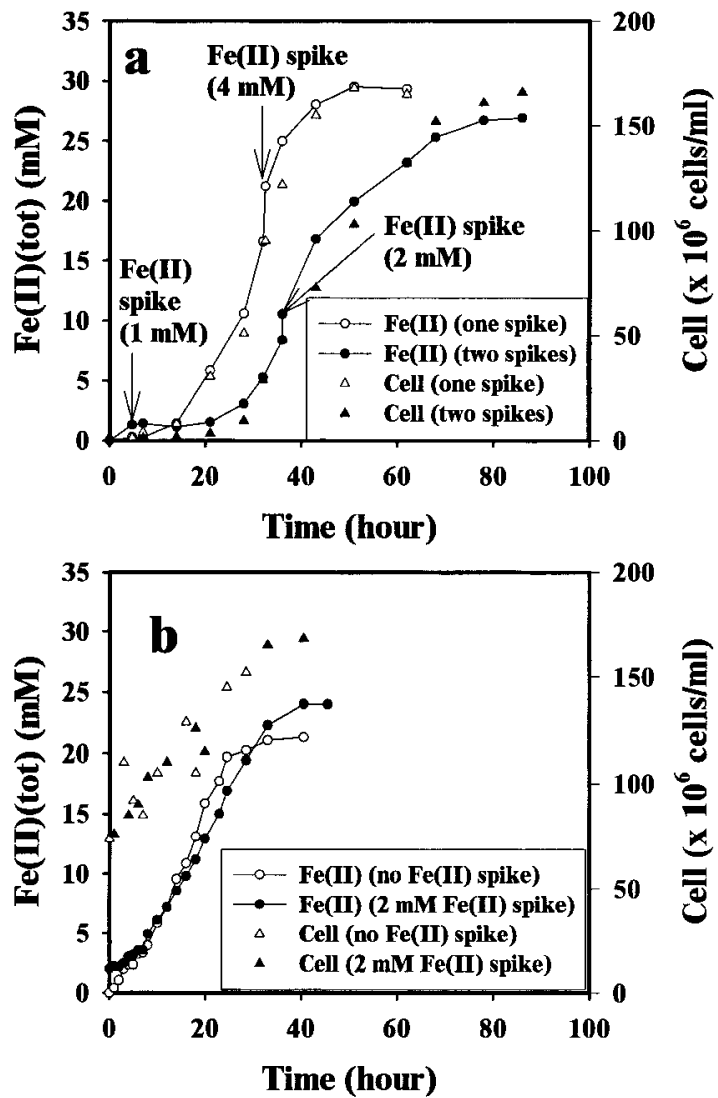

FIGURE 5. Effect of Fe(II) addition on Fe(II) production and cell grow th. (a) Fe(II) production and cell grow th with/w ithout an initial $\mathrm{Fe}$ (II) spike and with $\mathrm{Fe}$ (II) spike during the exponential grow th phase. (b) $24 \mathrm{mM}$ ferric-citrate/DIRB system $\left(7.4 \times 10^{7}\right.$ cells $\left./ \mathrm{mL}\right)$ with and without $\mathrm{Fe}(\mathrm{II})$ spike.

precipitates (e.g., like Figure 6a), indicating that growth and $\mathrm{Fe}$ (III) reduction commenced when the precipitates were somehow removed.

Femineral precipitation was thermodynamically feasible based on equilibrium Fe speciation calculations for the ferric-citrate system using both ASM-I and ASM-II. Calculated results using MINTEQA2 with both databases suggested that the ferric-citrate was supersaturated with respect to ferrihydrite $\left(\log \left(\mathrm{IQ} / \mathrm{K}_{\mathrm{sp}}\right)>5\right)$ at $\mathrm{pH} 7$ both without and with $\mathrm{FeCl}_{2}$ spike. The cell surfaces could provide nucleation sites to promote ferrihydriteprecipitation (30). However, practical experience with the ferric-citrate/ DIRB system indicates that the precipitation of ferrihydrite does not occur for extended period. The ferric-citrate system containing Fe(II) at concentration $>1 \mathrm{mM}$ [either from $\mathrm{Fe}(\mathrm{III})$ reduction or $\mathrm{Fe}(\mathrm{II})$ spike] was calculated to be supersaturated with respect to magnetite and $\mathrm{Cl}-$ and $\mathrm{SO}_{4}$ - green rusts using thermodynamic data from ref 69 . The ferric-citrate/ DIRB suspensions were calculated to be supersaturated with respect to these phases until the $\mathrm{Fe}(\mathrm{III})$ concentration decreased to below $0.5 \mathrm{mM}$. Greenish brown solution color was observed (ferric-citrate was dark brown) when $\mathrm{FeCl}_{2}$ was spiked to the suspension or when $\mathrm{Fe}(\mathrm{II})$ was produced through bioreduction. The greenish brown color transformed to dark greenish brown, and then became clear when all the Fe(III) was reduced. The greenish color suggested that green rusts might be the observed Fe precipitates on cell surfaces. Speciation calculations indicated that the spiking of the ferric-citrate medium with Fe(II), as performed to study the inhibiting effect of Fe(II), might displace some Fe(III) from the citrate complex by competitive mass action. This displaced $\mathrm{Fe}(\mathrm{III})$ would be reactive with $\mathrm{Fe}(\mathrm{II})$ in green rust 

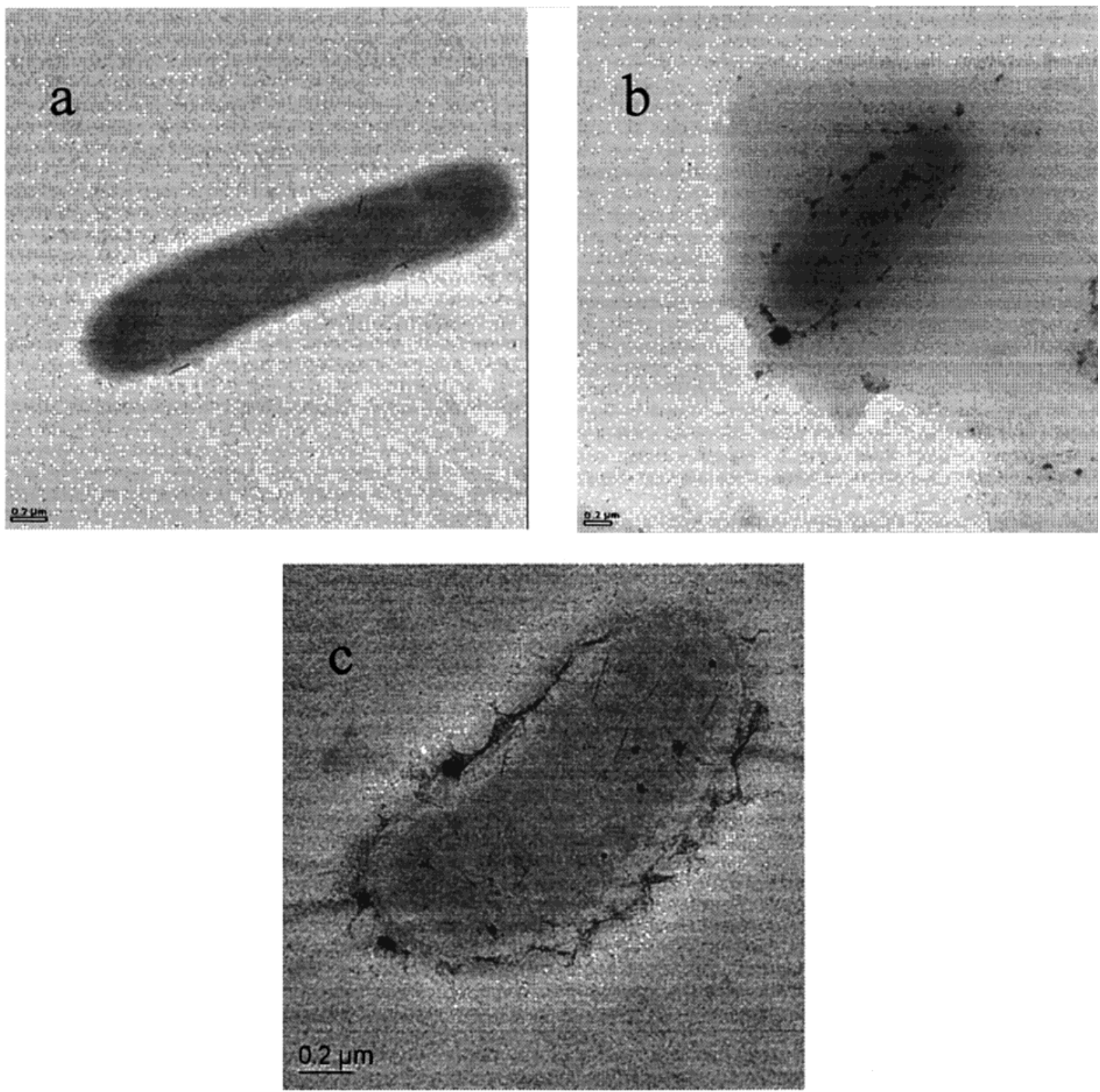

FIGURE 6. TEM images of $\mathrm{CN} 32$ sampled at different times after spiking a ferric-citrate medium with $\mathrm{FeCl}_{2}$. (a) $\mathrm{Cells}$ without Fe(II) spike. (b) Cells in lag phase ( $2 \mathrm{~h}$ after $\mathrm{FeCl}_{2}$ spike in Figure 5a). Electron dense materials are Fe mineral precipitates. (c) Cells about to recover from lag phase ( $15 \mathrm{~h}$ after $\mathrm{FeCl}_{2}$ spike; still in lag phase). Electron dense materials are Fe precipitates. Cell surface structure show $s$ evidence of vesicle formation.

formation. Further studies are underway to identify these mineral forms.

Fe(II) sorption and the surface precipitation of an $\mathrm{Fe}(\mathrm{II}) / \mathrm{Fe}(\mathrm{III})$ mixed solid may block or interfere with the electron transfer from CN32 to aqueous Fe(III). The surface precipitates [if Fe(III) containing] might also function as electron acceptors with different fundamental reduction rates. CN32 reduces magnetite at a much slower rate than aqueous Fe(III) (70, 71). The observed lag phase could result from either surface blocking or change in electron transfer pathway. At high cell concentration, there appeared to be excess surface area to accommodate Fe(II) sorption and Fe mineral precipitation. Thus, some cells were coated with mineral precipitates while others were not. The uncoated cells could function normally to reduce aqueous Fe(III) providing explanation for our observations of shorter lag periods at higher cell concentrations. A physiologic response of the cell to Fe mineral precipitation via a shedding-type mechanism might be instrumental to the cells' recovery
(Figure 6c). However, its growth/shedding mechanism and importance to the cell's recovery are, as yet, unclear.

Implications to Solid-Phase Fe(III) Reduction and Natural Environments. This study has shown that Fe(II) adsorbs to the surface of S. putrefaciens and that mineral precipitation on the DIRB surface may interfere with the bioreduction of Fe(III)aq. Similar phenomena may al so occur when theFe(III) form is a solid-phaseoxide. Wehaveobserved $\mathrm{Fe}(\mathrm{II})_{\text {aq }}$ concentrations ranging between 1 and $5 \mathrm{mM}$ in iron(III) oxide bioreduction experiments and also the formation of $\mathrm{Fe}(\mathrm{II})$-containing mineral precipitations on iron oxide surfaces $(23,24)$. Whether Fe(II)-containing minerals precipitate on cell surfaces and whether Fe(II) sorption and precipitation significantly influence iron(III) oxide bioreduction remain a point of conjecture. Fe(II) evolves slowly in iron(III) oxide bioreduction experiments, possibly allowing or triggering physiologic response of the DIRB to minimize inhibiting effects of Fe(II). Biosorption and Fe(II)-containing mineral precipitation are also accompanied by competitive 
sorption of Fe(II) to and Fe(II) mineralization on the residual oxide. These processes couplein complexfashion to produce integrated effects that have not been well studied.

$\mathrm{Fe}(\mathrm{II})_{\mathrm{aq}}$ is a common species in anaerobic sediment porewater and groundwater. Our results showed that $\mathrm{S}$. putrefaciens was able to recover from Fe(II)-induced inhibition and also to sustain $\mathrm{Fe}(\mathrm{III})$ reduction as $\mathrm{Fe}(\mathrm{II})$ accumulates. This recovery capability is apparently critical to thelong-term sustenance of bacterial iron(III) oxide reduction in the environment. However, kinetic model s of this complex biogeochemical process need to consider these recovery effects, e.g., the lag phase, particularly if DIRB are to be stimulated or added to subsurface systems for remediation purposes.

\section{Acknowledgments}

This research was supported by the Natural and Accelerated Bioremediation Research Program (NABIR), Office of Biological and Environmental Research (OBER), and U.S. Department of Energy (DOE). Pacific Northwest National Laboratory is operated for the DOE by Battelle Memorial Institute under Contract DE AC06-76 RLO 1830. We thank four anonymous reviewers for their valuable comments and advice.

\section{Literature Cited}

(1) Lovley, D. R. Microbiol. Rev. 1991, 55, 259-287.

(2) Lovley, D. R.; Phillips, E.J.; Lonergan, D. J. Environ. Sci. Technol. 1991, 25, 1062-1067.

(3) Lovley, D. R. Annu. Rev. Microbiol. 1993, 47, 263-290.

(4) Nealson, K.; Saffarini, D. Annu. Rev. Microbiol. 1994, 48, 311343.

(5) Lovley, D. R.; Philips, E. J. P. Appl. Environ. Microbiol. 1986, 51, $683-689$.

(6) Lovley, D. R.; Philips, E. J. P. Appl. Environ. Microbiol. 1988, 54, $1472-1480$.

(7) Myers, C. R.; Myers, J. M. Appl. Bacteriol. 1994, 76, 253-258.

(8) Lovley, D. R.; Baedecker, M. J.; Lonergan, D. J.; Cozzarelli, I. M.; Phillips, E. J.; Siegel, D. I. Nature 1989, 339, 297-299.

(9) Lovley, D. R.; Lonergan, D. J. Appl. Environ. Microbiol. 1990, 56, 1858-1864.

(10) Lovley, D. R.; Woodward, J. C.; Chapelle, F. H. Nature 1994, 370, 128-131.

(11) Chapelle, F. H. Ground-Water Microbiology and Geochemistry; John Wiley \& Sons: New York, 1993.

(12) Landa, E. R.; Philips, E. J. P.; Lovley, D. R. Appl. Geochem. 1991, $6,647-652$

(13) Donahoe, R. J.; Liu, C. Environ. Geol. 1996, 33, 143-153.

(14) Arnold, R. G.; Olson, T. M.; Hoffmann, M. R. Biotechnol. Bioeng. 1986, 28, 1657-1671.

(15) Tugel, J. B.; Hines, M. E.; Jones, G. E. Appl. Environ. Microbiol. 1986, 52, 1167-1172.

(16) Caccavo, F. J.; Blakemore, R. P.; Lovley, D. R. Appl. Environ. Microbiol. 1992, 58, 3211-3216.

(17) Lovley, D. R.; Philips, E. J. P. Appl. Environ. Microbiol. 1986, 52, $752-757$.

(18) Arnold, R. G.; DiChristina, T. J.; Hoffmann, M. R. Biotechnol. Bioeng. 1988, 32, 1081-1096.

(19) Fisher, F. G.; Pfanneberg, T. Zentralbl. Mikrobiol. 1984, 139, 163-166.

(20) Lovley, D. R.; Philips, E. J. P. Appl. Environ. Microbiol. 1987, $523,1536-1540$.

(21) Roden, E. E.; Zachara, J. M. Environ. Sci. Technol. 1996, 30, 1618-1628.

(22) Roden, E. E.; Urrutia, M. M. Environ. Sci. Technol. 1999, 33, 1847-1853.

(23) Zachara, J. M.; Fredrickson, J. K.; Li, S.-M.; Kennedy, D. W.; Smith, S. C. Am. Mineral. 1998, 83, 1426-1443.

(24) Fredrickson, J. K.; Zachara, J. M.; Kennedy, D. V.; Dong, H.; Onstott, T. C.; Hinman, N. W.; Li, S.-M. Geochim. Cosmochim. Acta 1998, 62, 3239-3257.

(25) Urrutia, M. N.; Roden, E. E.; Fredrickson, J. K.; Zachara, J. M. Geomicrobiology 1998, 15, 269-291.

(26) Roden, E. E.; Urrutia, M. M.; Mann, C. J. Appl. Environ. Microbiol. 2000, 66, 1062-1065.

(27) Lovley, D. R.; Coates, J. D.; Blunt-Harris, E. L.; Phillips, E. J. P.; Woodward, J. C. Nature 1996, 382, 445-448.
(28) Kukkadapu, R. K.; Zachara, J. M.; Smith, S. C.; Fredrickson, J. K.; Liu, C. Geochim. Cosmochim. Acta. (in press).

(29) Urrutia, M. N.; Roden, E. E.; Zachara, J. M. Environ. Sci. Technol. 1999, 33, 269-291.

(30) Ferris, F. G. Environ. Sci. Technol. 1999, 32, 2331-2337.

(31) Monod, J. Annu. Rev. Microbiol. 1949, 3, 371-393.

(32) Bae, W.; Rittmann, B. E. Biotechnol. Bioeng. 1996, 49, 683-689.

(33) Rittmann, B. E.; VanBriesen, J. M. Rev. Mineral. 1996, 34, 311.

(34) Salvage, K. M.; Yeh, G. T.; Cheng, H. P.; Cheng, J. R. In Computational Methods in Water Resources, XI; 1996; pp 517524.

(35) Van Cappellen, P.; Gaillard, J. F.; Rabouille, C. In Interactions of C, N, P, and Sbiogeochemical cyclesand gl obal change; Wollast, R., Mackenzie, F. T., Chou, L., Eds.; Springer: Berlin, 1993; pp 401-445.

(36) McNab, W. W.; Narasimhan, T. N. Water Resour. Res. 1994, 30, 2619-2635.

(37) Tebes-Stevens, C.; Valocchi, A. J.; VanBriesen, J. M.; Rittmann, B. E. J. Hydrol. 1998, 209, 8-26.

(38) Chilakapati, A.; Ginn, T.; Szecsody, J. E. Water Resour. Res. 1998, $34,1767-1780$.

(39) Wood, B. D.; Dawson, C. N.; Szecsody, J. E.; Streile, G. P. Water Resour. Res. 1994, 30, 1833-1845.

(40) Yeh, G. T.; Tripathi, V. S. Water Resour. Res. 1991, 27, 30753094.

(41) Viswanathan, H. S.; Robinson, B. A.; Valocchi, A. J.; Triay, I. R. J. Hydrol. 1998, 209, 251-280.

(42) Essaid, H. I.; Bekins, B. A.; Godsy, E. M.; Warren, E. Water Resour. Res. 1995, 31, 3309-3327.

(43) Clement, T. P.; Sun, Y.; Hooker, B. S.; Petersen, J. N. Ground Water Monit. Rem. 1998, Spring, 79-92.

(44) Steefel, C. I.; Van Cappellen, P. J. Hydrol. 1998, 209, 1-7.

(45) Allison, J. D.; Brown, D. S.; Novo-Gradac, K. J. MINITEQA2// PRODEFA2, A geochemical assessment model for environmental systems (version 3); Environmental Research Laboratory, U.S. EPA: Washington, DC, 1991.

(46) Davis, J. A.; Kent, D. B. Rev. Mineral. 1990, 23, 177-260.

(47) Beveridge, T. J.; Murray, R. G. E. J. Bacteriol. 1976, 141, 876887.

(48) Beveridge, T. J.; Koval, S. F. Appl. Environ. Microbiol. 1981, 42 $325-335$.

(49) Christ, R. H.; K., O.; Shank, N.; Nguyen, M. Environ. Sci. Technol. 1981, 15, 1212-1217.

(50) Harvey, R. W.; Leckie, J. O. Mar. Chem. 1985, 15, 333-344.

(51) Mullen, M. D.; Wolf, D. C.; Ferris, F. G.; Beveridge, T.J.; Flemming, C. A.; Bailey, G. W. Appl. Environ. Microbiol. 1989, 55, 31433149 .

(52) Goncalves, M. L. S.; Sigg, L.; Reutlinger, M.; Stumm, W. Sci. Total Environ. 1987, 60, 105-119.

(53) Fowle, D. A.; Fein, J. B. Geochim. Cosmochim. Acta 1999, 63, 3059-3067.

(54) Yang, J.; Volesky, B. Environ. Sci. Technol. 1999, 33, 751-757.

(55) Fein, J. B.; Daughney, C. J.; Yee, N.; Davis, T. A. Geochim. Cosmochim. Acta 1997, 61, 3319-3328.

(56) Volesky, B.; Holan, Z. R. Biotechnol. Prog. 1995, 11, 235-250.

(57) Daughney, C. J.; Fein, J. B. J. Colloid Interface Sci. 1998, 198, 53-77.

(58) Daughney, C. J.; Fein, J. B.; Tee, N. Chem. Geol. 1998, 144, 161176.

(59) IMSL. IMSL Library, Math/Library; Houston, 1991.

(60) Wiggins, B. A.; Jones, S. H.; Alexander, M. A. Appl. Environ. Microbiol. 1987, 53, 791-796.

(61) Linkfield, T. G.; Suflita, J. M.; Tiedje, J. M. Appl. Environ. Microbiol. 1989, 55, 2773-2778.

(62) Hunt, M. J.; Shafer, M. B.; Barlaz, M. A.; Borden, R. C. Biorem. J. 1997, 1, 53-64.

(63) Steven, N. L.; Baker, K. H. In Bioremediation; Baker, K. H., Herson, D. S., Eds.; McGraw-Hill: New York, 1994.

(64) Grady, C. P. L. J.; Smets, B. F.; Barbeau, D. S. Water Res. 1996, $30,742-748$

(65) Herbert, D. In Microbial Reaction to Environment, 11th Symposium of the Society of General Microbiology; 1961; pp 391416.

(66) Maaloe, O.; Kjelgaard, N. O. Control of Macromolecular Synthesis; W. A. Benjamin: New York, 1966.

(67) Koch, A. L. Adv. Microbiol. Physiol. 1971, 6, 147-217.

(68) Kono, T. Biotechnol. Bioeng. 1968, 10, 105-131.

(69) Genin, J.-M. R.; Refait, P.; Simon, L.; Drissi, S. H. Hyperfine Interact. 1998, 111, 313-318.

(70) Kostka, J. E.; Nealson, K. H. Environ. Sci. Technol. 1995, 29, $2535-2540$. 
(71) Dong, H.; Fredrickson, J. K.; Kennedy, D. W.; Zachara, J. M.; Kukkadapu, R. K.; Onstott, T. C. Chem. Geol. 2000, 169, 299318.

(72) Timberlake, C. F. J. Chem. Soc. 1964, 5078.

(73) Ribas, X.; Salvadó, V.; Valiente, M. J. Chem. Res. 1989, 1000, 2533-2553.

(74) Escoda, M. L.; de la Torre, F.; Salvadó, V. Polyhedron 1999, 18, 3269-3274.
Received for review July 21,2000 . Revised manuscript re ceived January 4, 2001. Accepted January 16, 2001.

ES0015139 